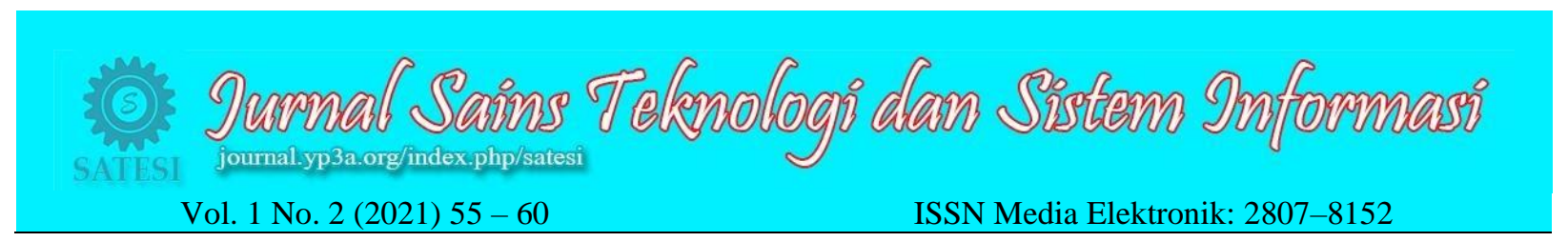

\title{
Penentuan Penampungan Korban Banjir Di Kecamatan Laweyan Kota Surakarta Berbasis Sistem Informasi Geografis
}

\author{
Moh. Ali Ma'sum ${ }^{1}$ \\ ${ }^{1}$ Fakultas Geografi, Universitas Muhammadiyah Surakarta \\ Email: adlimasoem@gmail.com
}

\begin{abstract}
One of the anticipation actions that can be done before the flood disaster comes is to determine the evacuation route and evacuation location or shelter for flood relief and spread to the public in order to accelerate the process of evacuation of disaster victims so as to minimize losses from the flood itself. This research was conducted by approaching Geographic Information System (SIG) The purpose of this research is (1) Knowing the flood-prone agihan in Laweyan Subdistrict based on SIG. (2) Analyze the Availability of Shelter Locations (Educational Buildings and Buildings of Worship) of flood victims in Laweyan Subdistrict. It is expected that in the research to know the potential of the best temporary evacuation shelter / protection and evacuation design so that it can be considered and help the relevant agencies, especially local BPBD in order to improve flood mitigation in Sumber Village, Banjarsari District, Surakarta City. To reduce or overcome the impact caused by flood disasters on the comfort and safety of the community in Laweyan Subdistrict, researchers need to raise the title, "Determination of Flood Victim Shelter in Lawean District of Surakarta City Based on Geographic Information System".
\end{abstract}

Keywords: Shelter, Flood, District Laweyan

\section{ABSTRAK}

Salah satu tindakan antisipasi yang dapat dilakukan sebelum bencana banjir datang adalah dengan menentukan rute evakuasi dan lokasi evakuasi atau tempat singgah untuk pertolongan bencana banjir dan di sebarkan kepada masyarakat luas demi untuk mempercepat proses evakuasi korban bencana sehingga dapat meminimalisir kerugian dari banjir itu sendiri. Penelitian ini dilakukan dengan pendekatan Sistem Informasi Geografis (SIG). Tujuan dari penelitian ini adalah (1) Mengetahui agihan rawan banjir di Kecamatan Laweyan berdasarkan SIG. (2) Menganalisis Ketersedian Lokasi Penampungan (Bangunan Pendidikan dan Bangunan Ibadah) korban banjir di Kecamatan Laweyan. Diharapkan pada penelitian mengetahui potensi tempat penampumhan/perlindungan sementara evakuasi terbaik dan desain evakuasi agar dapat dijadikan pertimbangan serta membantu instansi terkait khususnya BPBD setempat dalam rangka meningkatkan mitigasi banjir di Kelurahan Sumber, Kecamatan Banjarsari, Kota Surakarta. Untuk mengurangi atau mengatasi dampak yang ditimbulkan oleh bencana banjir terhadap kenyamanan dan keamanan masyarakat di Kecamatan Laweyan maka peneliti perlu mengangkat judul yaitu "Penentuan Penampungan Korban Banjir di Kecamatan Lawean Kota Surakarta Berbasis Sistem Informasi Geografis".

Kata Kunci: Penampungan, Banjir, Kecamatan Laweyan

\section{Pendahuluan}

Bencana akibat bahaya hidro-meteorologi seperti bencana banjir merupakan bencana yang setiap tahunnya mengancam wilayah-wilayah di Indonesia. Curah hujan yang tinggi setiap tahun nya di wilayah Indonesia, merupakan salah satu faktor yang dapat mendorong terjadinya bencana banjir. Peta perubahan normal curah hujan tahunan periode 1991-2010 terhadap 1971-1990 di Indonesia menunjukkan bahwa rata-rata wilayah di 
Indonesia mengalami peningkatan jumlah curah hujan. akan tempat pengungsian ini juga diakibatkan oleh Semua wilayah di pulau jawa mengalami kenaikan curah kurangnya kesadaran pemerintah setempat terhadap hujan dilihat dari warna hijau di peta tersebut, meskipun mitigasi bencana yaitu membuat shalter evakuasi atau ada beberapa wilayah yang menggambarkan tidak ada tempat perlindungan sementara, oleh karena itu perlu kenaikan curah hujan, tetapi untuk rata-rata wilayah di adanya upaya penanggulangan mitigasi bencana yaitu jawa mengalami kenaikan curah hujan yang signifikan, penentuan lokasi shalter dan desain evakuasi untuk yang paling terlihat signifikan yaitu wilayah provinsi bencana banjir. Salah satu tindakan antisipasi yang dapat Jawa Tengah. Curah hujan memang tidak bisa menjadi dilakukan sebelum bencana banjir datang adalah dengan satu patokan untuk memicu terjadinya bencana banjir. menentukan rute evakuasi dan lokasi evakuasi atau Menurut Nugroho (2015), Kepala Pusat Data Informasi tempat singgah untuk pertolongan bencana banjir dan di dan Humas Badan Nasional Penanggulangan Bencana sebarkan kepada masyarakat luas demi untuk mengatakan daerah yang sebelumnya jarang terjadi banjir mempercepat proses evakuasi korban bencana sehingga besar, saat ini makin rentan banjir akibat meningkatnya dapat meminimalisir kerugian dari banjir itu sendiri. hujan ekstrem, meningkatnya alih fungsi lahan, kerusakan daerah aliran sungai (DAS), 3 kerusakan lingkungan, berkembangnya permukiman di dataran banjir, dan lainnya. Risiko banjir akan meningkat ketika memasuki musim penghujan.

Bencana banjir disebagian wilayah Indonesia, hingga saat ini masih menjadi isu penting yang harus ditanggulangi. Menurut Sutupo Purwo Nugroho (2015) keadaan bancana banjir dengan tingkat kerawanan sedang hingga tinggi terbanyak yaitu di Provinsi Jawa Timur, Jawa Tengah dan Jawa Barat. Sedangkan menurut beliau daerah yang rawan banjir terdapat di sepanjang pantai timur Sumatra, Pantai Utara Jawa, Sungai Citarum, selatan Jawa Tengah (Jateng), pesisir Kalimantan, Papua, dan sekitar Sungai Bengawan Solo. Kejadian banjir pada Bulan April Tahun 2015 pernah menghebohkan Kota Solo dan sekitarnya. Daerah yang merupakan tempat kediaman Presiden Republik Indonesia Joko Widodo di Kelurahan Sumber, Kecamatan Banjarsari sempat terjadi banjir. Dikutip dari Merdeka.com dan Koran Sindo (2015), banjir tersebut adalah hasil dari luapan anak Sungai Pepe. Anak Sungai Pepe adalah anak sungai dari Sungai Bengawan Solo yang merupakan daerah rawan banjir.

Akibat luapan anak Sungai Bengawan Solo, banjir menggenangi ribuan rumah. Ketinggian banjir bervariasi yaitu mulai dari ketinggian $30 \mathrm{~cm}$ hingga 1,5 meter. Wilayah yang tergenang yaitu di Kelurahan Banyuanyar, Nunukan, Sumber, Banyuagung, Komplang, dan Kadipiro. Sebagian warga yang rumahnya tergenang memilih untuk mengungsi. Salah satu lokasi yang digunakan warga untuk mengungsi adalah gedung pertemuan Graha Saba milik Presiden Joko Widodo.

Banyak pengaruh atau kerugian-kerugian yang didapatkan akibat dari bencana banjir, hal ini bisa saja disebabkan oleh kurang tanggapnya masyarakat dalam menghadapi bencana banjir yang datang sehingga banyak masyarakat yang tidak tahu harus mengungsi kemana dan akhirnya resiko yang diambil yaitu menetap dirumah yang rawan tergenang banjir. Ketidaktahuan masyarakat
Dengan perkembangan teknologi Pengindraan Jauh dan SIG saat ini, identifikasi zona kerawanan bencana banjir dapat dilakukan dengan mudah, akurat dan dalam waktu yang relative cepat. Salah satunya adalah dengan menggunakan teknologi drone dan SIG. Penelitian ini dilakukan dengan pendekatan SIG), pendekatan ini merupakan salah satu metode di Sistem Informasi Geografis yang tergolong baru untuk sebuah penelitian di Indonesia. Suatu proses penggabungan teknik sosialisasi, pembuatan sketsa oleh masyarakat dan identifikasi melalui foto drone dengan resolusi $3 \mathrm{~cm}$ per pixel. Hasil akhir kegiatan ini adalah untuk mendapatkan daerah rawan banjir menggunakan data history. Diharapkan pada penelitian mendapatkan potensi tempat perlindungan sementara evakuasi terbaik dan desain evakuasi agar dapat dijadikan pertimbangan serta membantu instansi terkait khususnya BPBD setempat dalam rangka meningkatkan mitigasi banjir di Kelurahan Sumber, Kecamatan Banjarsari, Kota Surakarta. Untuk mengurangi atau mengatasi dampak yang ditimbulkan oleh bencana banjir terhadap kenyamanan dan keamanan masyarakat di Kecamatan Laweyan maka peneliti perlu mengangkat judul yaitu "Analisis Penentuan Lokasi Penampungan Korban Banjir di Kecamatan Lawean Kota Surakarta Berbasis Sistem Informasi Geografis Meode Buffering".

\section{Metode Penelitian}

2.1 Lokasi Penelitian

Lokasi Penelitian ini berada di Kecamatan Lawean, Kota Surakarta Jawa Tengah.

\subsection{Alat dan Bahan}

a. Laptop/PC

b. ArcGIS 10.2

c. Shp Kecamatan Laweyan

2.3 Metode Penelitian

Metode yang digunakan dalam penelitian ini yaitu modelling Sistem Informasi Geografis (metode Buffering. Modelling menggunakan ArcGIS 10.2

DOI: $10.54259 /$ satesi.v1i2.25

Lisensi: Creative Commons Attribution 4.0 International (CC BY 4.0) 
dilakukan dengan overlay atau penampalan beberapa data shapefile yang guna analisis cakupan banjir wilayah, sungai, jalan, pemukiman, fasilitas umum, dan jumlah penduduk menjadi sebuah data shapefile melalui adanya proses intersect menunjukkan kawasan terdampak banjir di Kecamatan Laweyan

Buffering merupakan dari teknik analisis yang mengidentifikasi hubungan antara suatu titik dengan area disekitarnya atau analisis factor kedekatan atau biasa disebut dengan Proximity Analysis. menggunakan batas tertinggi dari banjir yang pernah terjadi di Kecamatan Laweyan sebagai pedoman penentuan buffer yang akan diolah. Buffering dilakukan pada meter untuk penentuan lokasi potensi penampungan banjir Kecamatan Sayung. Penelitian ini hanya pada penentuan lokasi potensi penampungan banjir sehingga hasil terhadap olah data tidak terpacu pada aspek lain seperti jumlah penduduk

\section{Hasil dan Pembahasan}

Buffer merupakan salah satu fungsi yang terdapat dalam ArcGis. Dimana pembuatan buffering biasanya digunakan untuk kepentingan analisis yang dilakukan berdasarkan jarak atau zona tertentu. Buffer biasanya dibangun dengan arah keluar untuk melindungi elemenelemen spasial yang bersangkutan. Analisis buffer pada penelitian ini digunakan untuk mengidentifikasi zona potensi penampungan korban bencana banjir pada sarana ibadah dan sarana pendidikan di Kecamatan Laweyan Kota Surakarta Tahun 2018.

Persearan penampung korban banjir dibangunan sarana ibadah dan bangunan sarana Pendidikan Kecamatan laweyan bisa dilihat pada gamar 1 dan gambar 2 berikut.

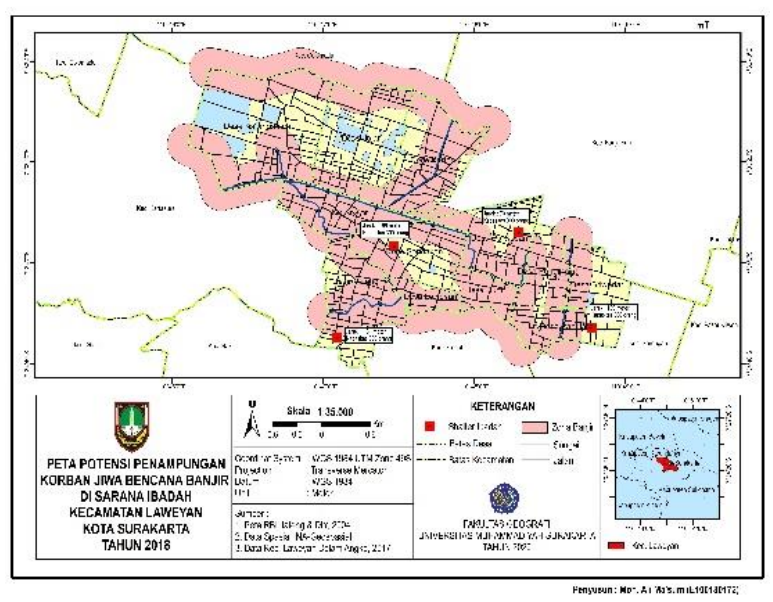

Gambar 1. Peta persebaran penampungan korban banjir di sarana Ibadah Kecamatan Laweyan

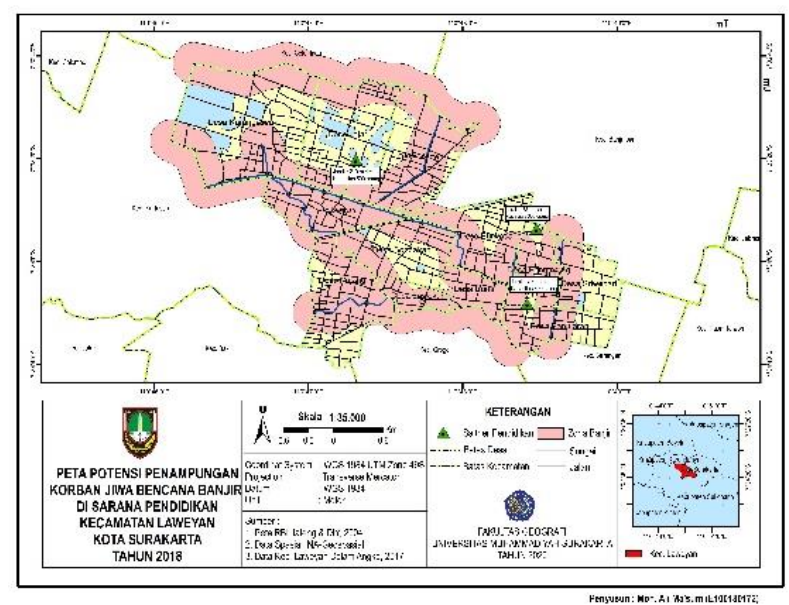

Gambar 2. Peta persebaran penampungan korban banjir di sarana Pendidikan Kecamatan Laweyan

Jumlah penduduk terdampak dan jumlah penampung/shalter di kecamtan laweyan dapat dilipat pada tabel1 dan tabel 2. (Tabel Perbandingan Jumlah Penduduk Terdampak dengan Kapasitas Shelter Ibadah dan Pendidikan).

Tabel 1. Perbandingan Jumlah Penduduk Terdampak dengan Kapasitas Shelter Ibadah

\begin{tabular}{lcc}
\hline Desa & $\begin{array}{c}\text { Penduduk } \\
\text { Terdampak }\end{array}$ & $\begin{array}{c}\text { Shalter } \\
\text { Ibadah }\end{array}$ \\
\hline Karangasem & 276 & 0 \\
Jajar & 0 & 0 \\
Kerten & 0 & 0 \\
Pajang & 0 & 300 \\
Purwosari & 0 & 300 \\
Sondakan & 3975 & 300 \\
Penumping & 0 & 0 \\
Sriwedari & 0 & 0 \\
Bumi & 0 & 0 \\
Laweyan & 0 & 0 \\
Panularan & 1 & 300 \\
\hline
\end{tabular}

Tabel 2. Perbandingan Jumlah Penduduk Terdampak dengan Kapasitas Shelter Pendidikan

\begin{tabular}{lcc}
\hline Nama Desa & $\begin{array}{c}\text { Penduduk } \\
\text { Terdampak }\end{array}$ & $\begin{array}{c}\text { Shalter } \\
\text { Pendidikan }\end{array}$ \\
\hline Karangasem & 276 & 0 \\
Jajar & 0 & 0 \\
Kerten & 0 & 500 \\
Pajang & 0 & 0
\end{tabular}




\begin{tabular}{lcc} 
Purwosari & 0 & 0 \\
Sondakan & 3975 & 0 \\
Penumping & 0 & 1000 \\
Sriwedari & 0 & 0 \\
Bumi & 0 & 0 \\
Laweyan & 0 & 0 \\
Panularan & 1 & 0 \\
\hline
\end{tabular}

Untuk mempermudah mebandingkan jumlah korban terdampak dengan penampung korban banjir di sarana Ibadah dan Pendidikan Kecamatan Laeweyan bisa dilihat pada gambar 3 berikut.

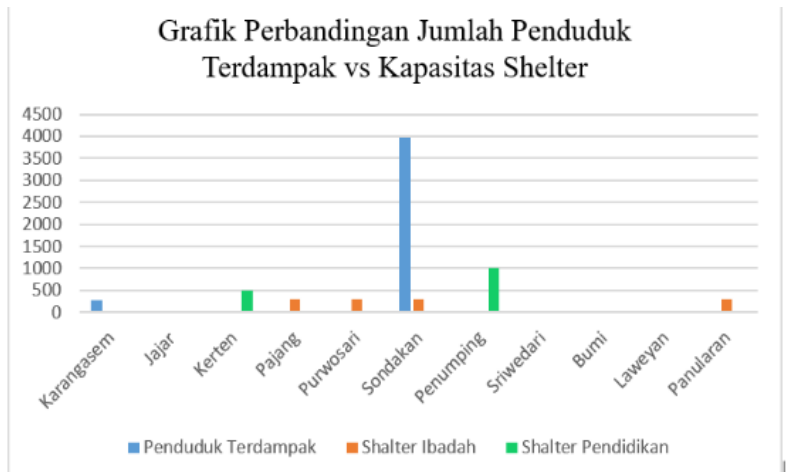

Gambar 3. mebandingkan jumlah korban terdampak dengan penampung korban banjir di sarana Ibadah dan Pendidikan di kecamatan Laweyan

Penampungan korban bencana banjir di sarana ibadah di kecamatan Laweyan Kota Surakarta terdapat 4 shalter, shalter tersebut terdapat di Desa Pajang dengan jarak 131 meter dari zona banjir, Desa Purwosari 70 meter dari zona banjir, Desa Panularan 109 meter dari zona banjir dan Desa Sondakan 166 meter dari zona banjir. Setiap shalter tempat ibadah memiliki kapasitas 300 orang jadi total sekitar 1.200 orang yang bisa di tampung di shalter ibadah.

Sedangkan untuk penampungan korban bencana banjir di sarana pendidikan di kecamatan Laweyan Kota Surakarta terdapat 3 shalter, satu shalter terdapat di Desa kerten dengan jarak 210 meter dari zona banjir dan dua shalter terdapat di Desa Penumping dengan masing masing jarak ke zona banjir 70 dan 78 meter. Setiap shalter sarana pendidikan memiliki kapasitas 500 orang jadi total sekitar 1.500 orang yang bissa di tampung di shaltersarana pendidikan.

Jumlah shalter tempat ibadah jika dilhat dari segi jumlahnya lebih banyak yaitu 4 shalter dibanding dengan shalter sarana pendididkan yang hanya 3 shalter saja. Namun jika dilihat dari jumlah kapasitas penampungan justru lebih banyak shalter sarana pendidikan yaitu dengan total kapasitas 1500 orang sedangkan sahalter tempat ibadah hanya menampung 1200

Dilihat dari penduduk yang terdampak banjir di kecamatan laweyan terdapat tiga Desa yang terdampak yaitu Desa karangasem dengan jumlah penduduk sekitar 276 orang, yang kedua Desa Sondakan terdapat sekitar 3975 orang yang terdampak yang terakhir Desa Panularan terdapat satu orang yang terdampak.

Jumlah total penduduk terdampak jika dikalkulasikan sekitar 4.257 orang hal ini menunjukan bahwa kapasitas penampung korban banjir tidak cukup untuk menampung semuanya, karena jika kapasitas jumlah penampung korban di tempat ibadah dan sarana pendidikan saja hanya sekitar 2.700 .

Dapat disimpulkan bahwa hasil buffer disini sangat bermanfaat dimana bisa menjadi acuan pihak terkait untuk mengevaluasi apa saja yang kurang atau perlu ditingkatkan dan yang perlu dipertahankan dalam penanganan banjir supaya meminimalisir menimbulkan korban jiwa dan insfratuktur Kesimpulan

Jumlah shalter tempat ibadah jika dilhat dari segi jumlahnya lebih banyak yaitu 4 shalter dibanding dengan shalter sarana pendididkan yang hanya 3 shalter saja. Namun jika dilihat dari jumlah kapasitas penampungan justru lebih banyak halter sarana pendidikan yaitu dengan total kapasitas 1500 orang sedangkan sahalter tempat ibadah hanya menampung 1200

Jumlah total penduduk terdampak jika dikalkulasikan sekitar 4.257 orang hal ini menunjukan bahwa kapasitas penampung korban banjir tidak cukup untuk menampung semuanya, karena jika kapasitas jumlah penampung korban di tempat ibadah dan sarana pendidikan saja hanya sekitar 2.700 .

Hasil buffer disini sangat bermanfaat dimana bisa menjadi acuan pihak terkait untuk mengevaluasi apa saja yang kurang atau perlu ditingkatkan dan yang perlu dipertahankan dalam penanganan banjir supaya meminimalisir menimbulkan korban jiwa dan insfratuktur.

\section{Referensi}

[1] Aqli, Wafirul. 2010. Analisa Buffer dalam Sistem Informasi Geografis untuk Perencanaan Ruang Kawasan. INSERSIA. 2(1): 192-201. Dari https://journal.uny.ac.id/index.php/inersia/ article/viewFile/10547/8063

[2] Prahasta, E. 2007. Sistem Informasi Geografis: Tutorial ArcView. Bandung: Informatika.

[3] Prahasta, E. 2002. Sistem Informasi Geografis: Konsep-Konsep Dasar. Bandung: Informatika.

[4] Prahasta, Eddy. 2009. Sistem Informasi Geografis Konsep-Konsep Dasar. Bandung: Informatika.

[5] Wibowo T W. 2013. Pelatihan Sistem Informasi Geografis untuk Pengelolaan Kawasan Konservasi Tingkat Lanjut. Yogyakarta (ID) : Fakultas Kehutanan Universitas Gadjah Mada 
Lampiran Peta Penampungan Korban Banjir (Sarana Iadah dan Pendidikan) Kecamatan Laweyan

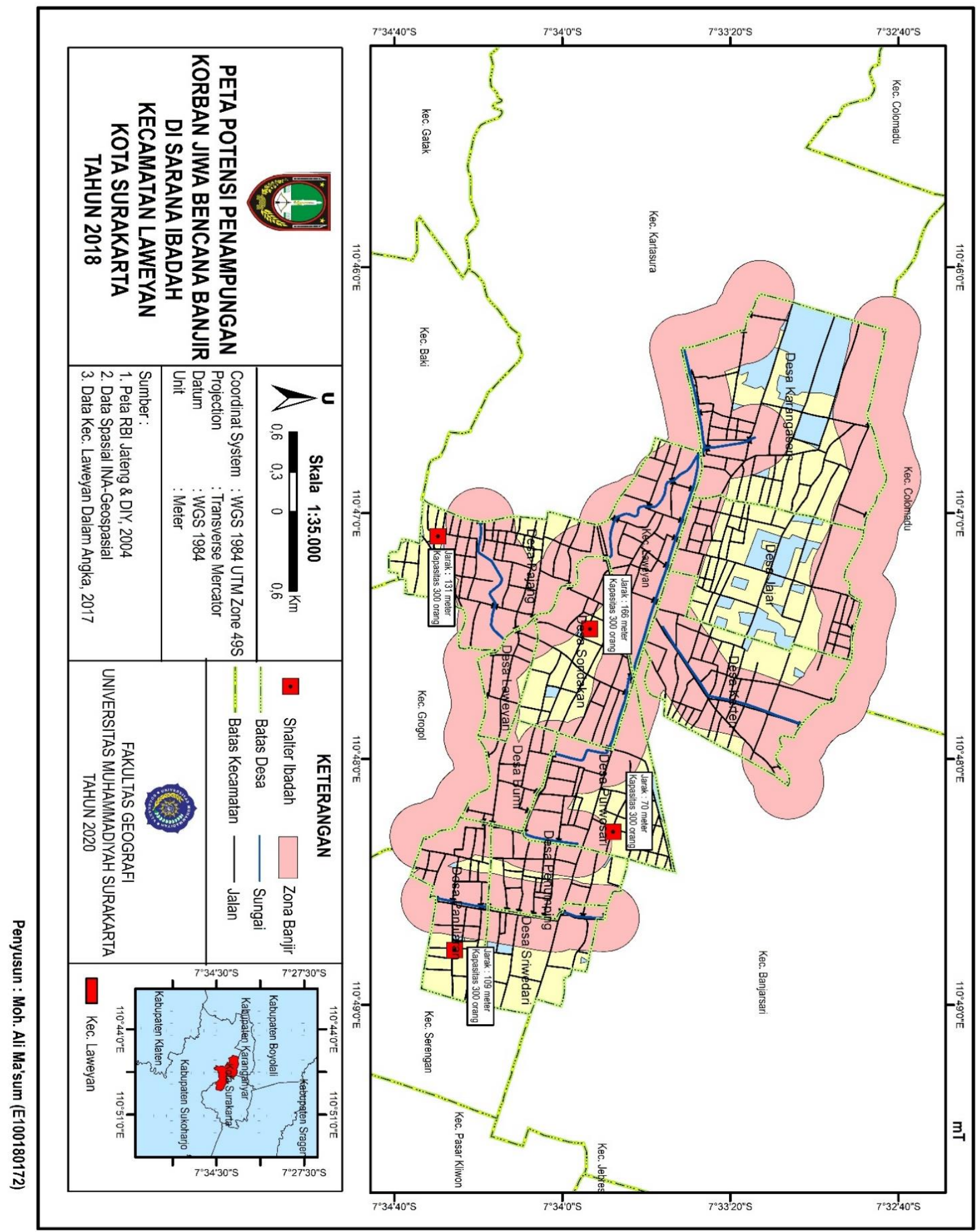




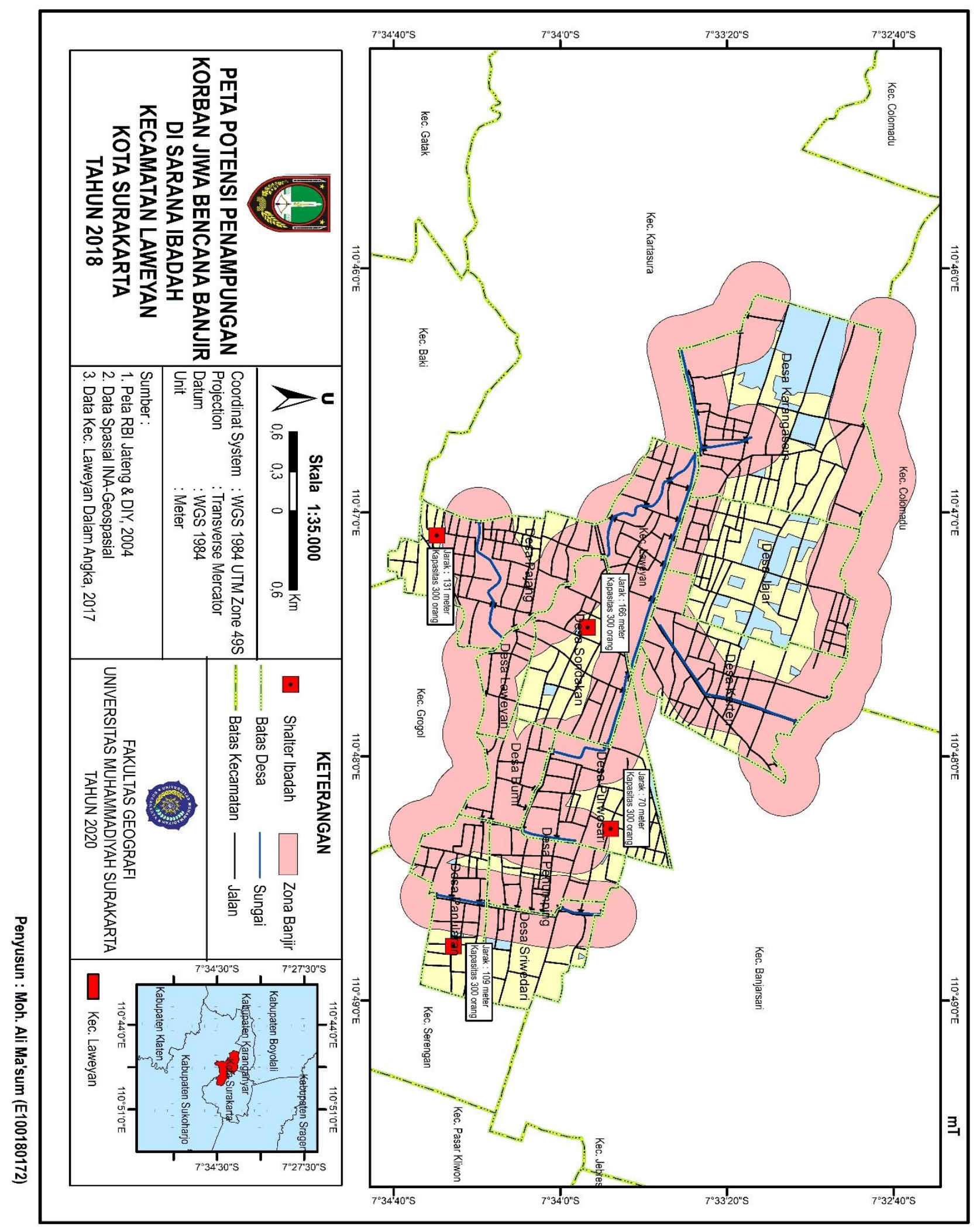

DOI: $10.54259 /$ satesi.v1i2.25 